\title{
Migration Amidst Climate Rigidity Traps: Resource Politics and Social-Ecological Possibilism in Honduras and Peru
}

\author{
David J. Wrathall, ${ }^{*}$ Jeffrey Bury, ${ }^{\dagger}$ Mark Carey,${ }^{\ddagger}$ Bryan Mark, ${ }^{\S}$ Jeff McKenzie, ${ }^{*}$ Kenneth Young, ${ }^{\pi}$ \\ Michel Baraer, ${ }^{£}$ Adam French, ${ }^{\sharp}$ and Costanza Rampini ${ }^{\dagger}$ \\ *Institute for Environment and Human Security, United Nations University \\ †Department of Environmental Studies, University of California Santa Cruz \\ ${ }^{\ddagger}$ Clark Honors College, University of Oregon \\ ${ }^{\S}$ Department of Geography, The Ohio State University \\ ${ }^{*}$ Department of Earth and Planetary Sciences, McGill University \\ ${ }^{\mathrm{T}}$ Department of Geography and the Environment, University of Texas, Austin \\ ${ }^{E}$ École de technologie supérieure, Université du Québec \\ ${ }^{\ddagger}$ Energy and Resources Group, University of California, Berkeley
}

\begin{abstract}
According to dominant narratives about adaptation to climate change, those facing worst-case scenarios, without means at their disposal to adapt in situ, face an ineluctable set of adaptation strategies that ultimately includes the permanent abandonment of geographic spaces rendered uninhabitable and unproductive for human use. Yet environmental stress and adaptive capacity are distributed unevenly, and power structures play a role in fashioning them. It is argued here that when access to land and water are impacted by environmental stress, the structures that mediate their access are reinforced, even as the adaptive alternatives for smallholders are undermined. In this way, dominant resource regimes set up migration as the primary viable alternative for adaptation among a dwindling set of choices. This framework is applied to two early analogues of climate change impacts: flooded Garífuna villages of Honduras's North Coast and communities enduring glacier recession and shifting hydrologic regimes in Peru's Cordillera Blanca. In both cases, stress motivates new forms of migration that reinforce dominant power structures. In Honduras, migrants from wealthier social strata are moving on a more permanent basis, and in Peru, the once historical pattern of labor migration is becoming a practical necessity. These cases underscore the role of political economy in adaptation to climate change and adaptive migration in particular. Key Words: adaptation, climate change, migration, political ecology, social-ecological systems.
\end{abstract}

根据适应气候变迁的主流叙事, 面对最恶劣的情势却未能掌握适应现况工具者, 面临着一连串不可避免的调试策略, 这些策略终将包含永远遗弃那些成为不适合人类居住、且无法进行生产的地理空间。但环境压力与适应能力呈现出 不均分配, 而权力结构在形塑此般不均分配中, 扮演着特定的角色。本文主张, 当获取土地与水的管道受到环境压力 影响时, 调节这些管道的结构会受到进一步强化, 即便当小农的另类适应方法受到损害时。主流的资源体制, 便藉此 在逐渐缩小的选择组合中, 将迁徙设定为适应的首要可行方案。此一架构被应用于气候变迁冲击的两个早期相似案 例: 洪都拉斯北部海岸遭受洪泛的加利福纳 (Garífuna) 村落, 以及秘鲁布兰卡山脉 (Cordillera Blanca) 中饱受冰川后 退与水文体制变迁所苦的社区。在两个案例中, 压力同时驱动了巩固主流权力结构的新迁徙形式。在洪都拉斯, 来 自较为富裕的社会阶层的迁徙者, 其迁徙有着较为永久、稳固的基础。而在秘鲁, 历史中的劳动迁徙模式正逐渐成 为实际的必要性。这些案例凸显出适应气候变迁, 特别是适应性的迁徙中, 政治经济的重要性。关键词: 适应, 气候 变迁, 迁徙, 政治生态学, 社会一生态系统。

De acuerdo con las narrativas corrientes acerca de la adaptación al cambio climático, quienes se enfrentan a los escenarios de la peor clase, sin medios a su disposición para adaptarse in situ, tienen que encarar un conjunto ineludible de estrategias de adaptación que en últimas incluyen el abandono permanente de espacios geográficos que se han vuelto inhabitables e improductivos para uso humano. Pero el estrés ambiental y la capacidad adaptativa se distribuyen desigualmente, y las estructuras de poder juegan un papel importante en su formación. Aquí se sostiene que cuando el acceso a la tierra y al agua es impactado por estrés ambiental, las estructuras que intervienen en su acceso son reforzadas, aun a expensas de las alternativas adaptativas para los pequeños propietarios. De esa manera, los regímenes de recursos dominantes colocan a la migración como la alternativa 
viable primaria de adaptación entre un conjunto de opciones cada vez más limitado. Este esquema se aplica a dos análogos tempranos impactados por el cambio climático: aldeas garífunas afectadas por inundación en la Costa Norte de Honduras y comunidades que padecen cambiantes regímenes hidrológicos en la Cordillera Blanca del Perú por la recesión de glaciares. En ambos casos el estrés motiva nuevas formas de migración que refuerzan las dominantes estructuras de poder. En Honduras, los migrantes de los estratos sociales pudientes se desplazan de una manera más permanente, y en el Perú, el que en otros tiempos fuera un patrón histórico de migración laboral se está convirtiendo en una necesidad práctica. Estos casos descubren el papel de la economía política en la adaptación al cambio climático y sobre la migración adaptativa en particular. Palabras clave: adaptación, cambio climático, migración, ecología política, sistemas socio-ecológicos.

$\mathrm{G}$ lobal climate change scenarios warn that human landscapes could become uninhabitable, unproductive, or otherwise unfit for human use due to increasing storm surges, melting glaciers, and changing rainfall regimes (Intergovernmental Panel on Climate Change 2012; World Bank 2012). In worst-case scenarios, environments are more hazardous, negative impacts occur in livelihoods and economic opportunities, and conflicts develop over dwindling resources. Looking for early analogues of things to come, new research is focusing on migration dynamics taking place in climate "hot spots," or vulnerable regions across the planet where environmental stresses are spatially concomitant with poverty and rapid demographic change (Hugo 2011). Two key conclusions of this research are that migration is either occurring because it is a strategy for adapting to adverse conditions (McLeman and Smit 2006; Bardsley and Hugo 2010) or because local populations lack the capacity to adapt (Renaud 2007; Tacoli 2009).

Although climate change scenarios often assume that some populations must adaptively migrate as their landscapes are made unproductive by forces beyond their control, this brand of environmental determinism is contested by human geographers and political ecologists who point to the complex and uneven geographies of human vulnerability across scales of analysis as well as the ways in which adaptation is limited by institutional rigidity, governance inefficiencies, or pathway dependency (Adger et al. 2009; Liverman 2009; Peet, Robbins, and Watts 2011). The unequal distribution of these adaptation alternatives highlights the political mechanisms that constrain or expand agency and raise questions about who produces what kinds of social-environmental relationships and for whom (Heynen, Kaika, and Swyngedouw 2006; Eakin et al. 2009; Carey, Huggel et al. 2012). In this sense, environmental migration should not be considered environmentally predetermined but rather as an expression of political economy as well.

This article builds on these discussions by arguing for an adaptive systems framework that more effectively incorporates political economy. It then comparatively examines how political structures influence adaptation alternatives in two distinct case studies where climate stresses are motivating migration and where these stresses are advancing rapidly. These include disappearing glaciers in Peru and the intensification of tropical storms at sea level in Honduras. Climatic stresses are undermining the availability of coastal land (in Honduras) and water resources (in Peru), but also in each case study, political economies have developed around these key resources and mediate access to them. This article hypothesizes that a systems approach to adaptation that accounts for the structures that govern access to changing resources is appropriate regardless of the particular setting; to the extent that we can apply such an approach to these highly contrasting environments (with distinct social, political, and economic histories), this substantiates its applicability in understanding migration as adaptation to climate change.

\section{Political Economy as the Basic Structure of Adaptive Systems}

Decisions about migration are influenced not only by climatic and other environmental changes but also by a constellation of other drivers beyond the household level, such as economic scarcity, political pressure, socioeconomic aspirations, and cultural values (Black, Bennett, et al. 2011). Climate stress also feeds back into these social processes by impacting a range of socioeconomic factors that present opportunities for migration, such as education, access to services, access to health care, remittances, income decline, and income variability (Hugo 2008; Feng, Krueger, and Oppenheimer 2010; Raleigh and Jordan 2010; Lilleør and Van den Broeck 2011). Simultaneously, a clearer picture is emerging of the context-specific constraints on human migration behavior: Women possess different migration alternatives from men, young people from the elderly, and the relatively wealthy from the poor (McLeman and Hunter 
2010; Gray and Mueller 2012). In addition, these constraints also lead people to remain in hazardous areas when short-term benefits outweigh the risks associated with potential hazards or when they identify risks associated with mobility (Carey 2010; Black, Adger, et al. 2011).

Adaptive migration is commonly framed as a question of livelihood resilience, and it is argued here that resource inputs for livelihoods are linked to dynamics at higher scales. Under "normal" conditions, household livelihood strategies depend on social-ecological relationships that channel the essential inputs to human life, like water and fertile soil, that enable productive livelihoods and permit relatively stable modes of human settlement (Hummel et al. 2012). These fundamental relationships confer capacity to resist change or resilience to reorganize in the aftermath of a disturbance (Folke 2006; Loarie et al. 2009), but environmental disturbance (including climate stress) can also suddenly and catastrophically overwhelm livelihood systems (Anderies, Walker, and Kinzig 2006; Walker et al. 2006; Scheffer et al. 2009). When livelihood systems can no longer absorb stress, people migrate (Wrathall 2012).

The availability of land and water are stabilizing influences in rural livelihood systems, but these are embedded into a set of power relations, practices, and institutions that mediate access (Leach, Mearns, and Scoones 1999; Rocheleau 2008). Of particular concern are the institutional structures of domination and the authorities, politics, and mechanisms that determine resource distribution in society (Giddens 1984; Pelling and Manuel-Navarrete 2011). Dominant structures, for example, might include a water allocation regime or a land tenure policy, which, over the course of time, order specific resources and modes of resource accumulation. These structures create periods of systemic stability, and despite a tendency to be excessively rigid, they are often able to withstand significant stress because they are maintained through the exercise of coercive power (Scheffer et al. 2002; Carpenter and Brock 2008). In this way environmental stress might in fact reinforce and amplify dominant structures, even while altering or dissolving the resource relationships that undergird livelihood stability at household levels. This increasingly inflexible systemic state, in which adaptation alternatives rapidly diminish, is called a rigidity trap (Allison and Hobbs 2004). In this way, political economy sets up migration as an increasingly viable adaptation alternative among a dwindling set of adaptive choices.

\section{Resource Politics and Climate Stress in Honduras and Peru}

To more carefully examine the relationship between dominant political structures and adaptive migration, case studies in Honduras and Peru were selected for comparative analysis. The rationale for selecting these locations is based on the similarly strong influence that institutional structures exert over access to essential resources-land in the case of Honduras and water in Peru. The resource regimes in these contexts-embodied in Honduras's 1992 Law for the Modernization and Development of the Agricultural Sector, and Peru's 2009 Water Resources Law—shifted over the last few decades, with most of Latin America in a neoliberal alignment toward a commoditization and marketization of natural resources (Jansen and Roquas 1998; Budds and Hinojosa 2012). Additionally, in both cases, climate stresses-intensification of storms and sea level rise in Honduras and melting glaciers in Peru-also alter access to these essential resources, undermining the bases of rural livelihoods and motivating migration. For these two converging reasons, a multimethod quasi-experimental comparative approach was used to examine the role of dominant political structures in ordering alternatives for adaptive migration. The sites are presented as a continuum of exposure, forming the basis for a quasi-experimental comparison of migration behaviors by analogy (McLeman and Hunter 2010).

\section{Tropical Storms, Dominant Land Tenure Structures, and Migration in Honduras}

We are currently in the midst of an active decadal cycle of Atlantic cyclones, and more energetic storms are linked to increasing average sea surface temperatures (Bender et al. 2010). Named tropical storms have made landfall in northern Honduras in twelve of the last fourteen years, and villages at sea level among estuarial zones are experiencing a pattern of catastrophic flooding and permanent, irreversible erosion of land, rendering population centers uninhabitable. One particular Afroindigenous group, the Garifuna, arrayed in over fifty settlements, is on the frontline of exposure (Cochran, Reese, and Liu 2009; Wrathall 2012). Almost without exception, villages share common environmental features that increase local susceptibility to land loss: immediate proximity to sea level; a geological substrate of loamy sand; proximity to fresh water sources; proximity to the steep, (de)forested mountain ranges 

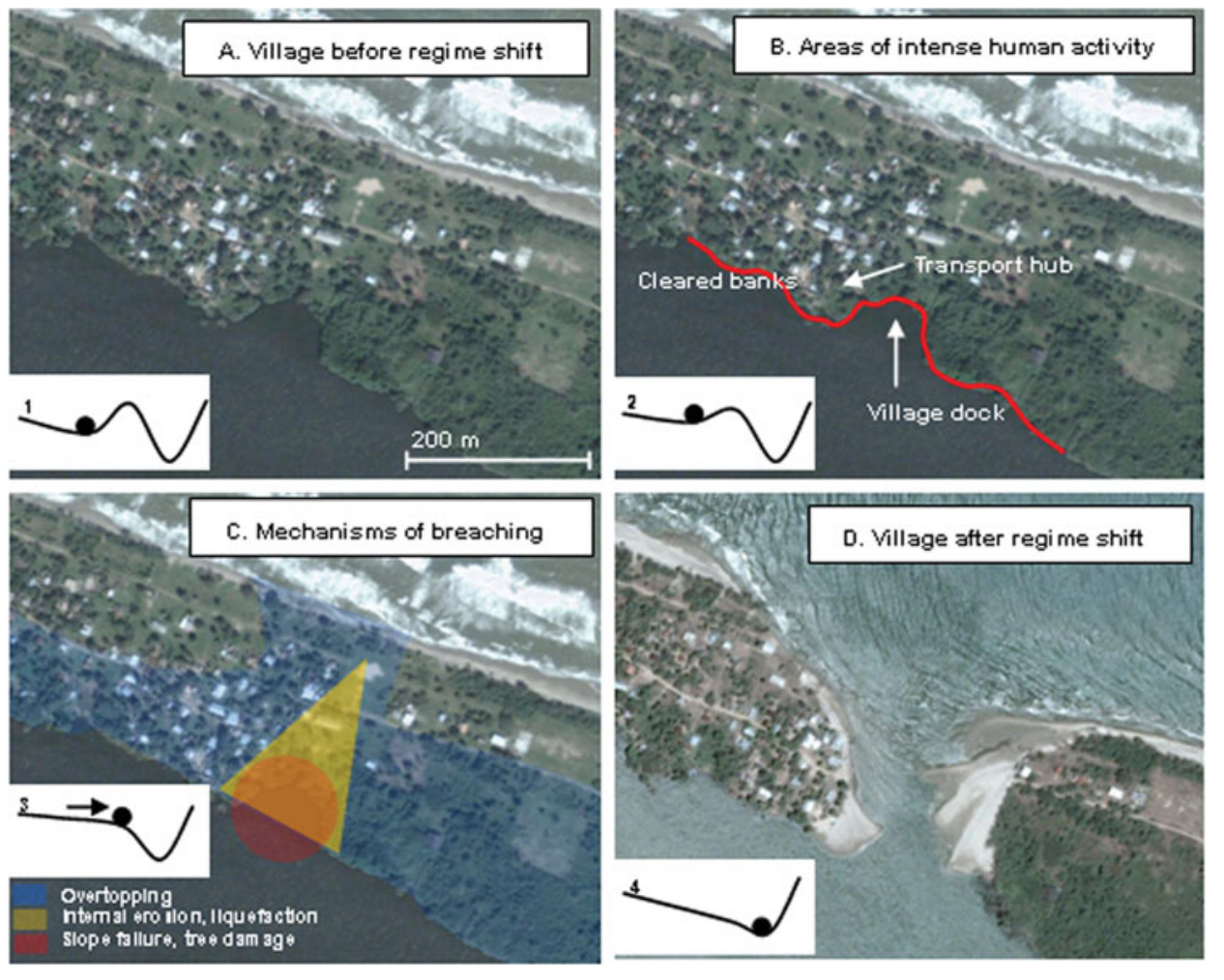

Figure 1. (A) and (B): Batalla, Honduras, in 2003 moving toward a social-ecological threshold. (C) The compounding environmental stressors associated with Topical Depression Gamma that breached thresholds in November 2005. (D) Batalla, Honduras, in 2006 in a new stable state. (Color figure available online.) of Honduras's interior; and exposure to wind, rainfall, and storm surges associated with tropical storms. A combination of cascading biophysical mechanisms (including slope failures, overtopping, tree damage, and internal erosion and liquefaction) together produce a sudden, catastrophic shift that can occur within hours (Figures 1C and 1D). These catastrophic shifts have occurred already in eight villages and more villages have been identified as vulnerable. Mixed-method vulnerability mapping and ethnographic research were conducted in three of these communities at different stages of exposure: Santa Rosa de Aguán (acute, progressive, and repetitive flooding with $>300$ households displaced between 1998 and 2009), Batalla (acute, albeit more recent flooding with $>30$ households displaced between 1998 and 2009), and Iriona (general flooding with $<10$ households displaced between 1998 and 2009).

The Garífuna of northern Honduras have a complex and storied historical relationship to land tenure and migration, involving pre-Columbian ancestry and traditions, the African slave trade, mercantilism in the eastern Caribbean, and forced exile to Honduras at the hands of the British in 1797 (Gonzalez 1988). At various stages, en route to Honduras, the Garifunas have been marginalized by (and have fiercely resisted) the dominant land tenure regimes of historical periods. Subsequent to the their arrival in Honduras, where this analysis focuses, the extant land tenure regimes relegated Garifuna settlements to the estuaries and small river deltas of the coastal littoral (García 2001). During the colonial hacienda period of the nineteenth century and the neocolonial era of the North American banana companies of the twentieth century, land use conventions constrained access to land in Honduras's interior, confining the geographical extent of Garífunas' farming practices to a narrow fringe of marginal mainland immediately adjacent to settlements (García 2004; Soluri 2005). Responding to land scarcity and insecurity, the Garífuna engaged in mobile livelihoods based around fishing and maritime trade across the Bay of Honduras through the nineteenth and twentieth centuries. By the end of the twentieth century, the Garifuna's transoceanic livelihoods situated them as longshoremen, navigators, and merchant marines throughout North America and beyond, and this transformed them into a community in diaspora-albeit one with an eye fixed homeward (England 2006; Anderson 2009). Migration historically served the primary goal of remitting incomes to the village. Ricardo explained:

To achieve upward mobility, to save money, to build a house, it has always been thus that young people migrate. And the idea traditionally is to return. Always! You would work until you earned enough to establish a base: maybe a 
restaurant, or a ranch, or an import-export business. Then you could live very well in the village. You may not have a fat life here, but you would be very comfortable.

The dominant structures around land ownership in northern Honduras amplified during the latter half of the twentieth century and have articulated with environmental stress to influence forms of adaptive migration that are essentially distinct from historical patterns. The new dynamic interrupts the linkages between migrants (with their earnings) and their ancestral villages.

In 1992, a new neoliberal policy, the Law for the Modernization and Development of the Agricultural Sector, aligned with and amplified long-standing structures around land ownership. The policy mechanism intended to formalize informal land tenure across the country, exalting land commodification and even imposing privatization on land cooperatives (Jansen and Roquas 1998). The policy enforced a prior constitutional entitlement to communal lands for ethnic communities, like the Garífuna, but the impact of the policy varied among communities. Communally titled lands generally came under immediate threat from both powerful economic actors, as well as marginalized campesinos. The law provided industrial plantation owners a favorable policy environment for monopolizing farmland on the coastal plains, easing restrictions on the amount of land that a legal entity could possess. In the cases of the Garifuna communities of Limón and Punta Piedra, ancestral lands were effectively surrounded by large industrial plantations and midscale cattle ranches (García 2004).

Land competition driven by economically powerful actors has also created conditions for conflict among marginalized social strata. Although conflicts over land between Garífunas and local Miskitus have occurred historically (Mollett 2006), new land scarcity enflamed tensions between Garífunas and immigrant campesinos from western Honduras. Under the 1992 law, although land invasions were prohibited, nonindigenous campesinos who could show peaceful homesteading occupancy were eligible for formal land rights. In short, this produced a number of invasions within indigenous territories (Mollett 2011) and began a series of sustained challenges to communal control of Garífuna territory, such as the ongoing conflicts in Iriona, and near Punta Piedra, where each party is justifying its respective claims on the basis of the 1992 land laws.

The most troubling feature of this Honduran brand of neoliberalism is the extent to which land transfers were not only mediated by the private market but also through coercion, impunity, and naked violence. The recent bloody conflict over land in Bajo Aguán-adjacent to one of the study sites but not directly affecting Garifunas-is one manifestation of this tendency (Bird 2011). In the words of one respondent reporting on this common theme near Iriona, midscale cattle ranchers would "cut down the Garífunas' fence posts, and introduce cattle in our land. They wait for you to complain with a pistol in their belt." There is little recourse in the courts, as the judicial process favors enterprises with legal representation and is highly corruptible regardless. Maria reported:

People often see themselves as obligated to cede or sell their lands, sometimes under threat of violence, for concern about their lives and their families. Municipal authorities even lend themselves to these misdeeds because land is lucrative. Threats or not, the thing is, if someone takes a liking to your property for one reason or another, they will make your life impossible until they obtain it.

In the cases of Laguna de Zambuco, Rosita, Nueva Go, and Cayo Venado, landowning estates have allegedly fenced traditional Garífuna plots or introduced cattle (García 2004).

This insecurity and land scarcity has transformed land into cultural obsession and a centerpiece of Garífuna political solidarity (Anderson 2007), but meanwhile at local levels, because land is limited, Garífuna livelihoods are increasingly concentrated in and around the villages, putting significant environmental pressure on the geological substrate and local ecology. Fishing, trading, intensive subsistence agriculture, and small-scale cattle ranching are the core of village economic systems, and these activities require docks, markets, and transport hubs, and in some areas, mangroves are cleared to provide space for pasture (Cochran, Reese, and Liu 2009). Moreover, the intensification that accompanies these activities - foot, boat, car, and livestock traffic - serves to disarticulate loose soil structures that prevent erosion. Thus, the overall environmental state of Garífuna villages is increasingly intense activity on increasingly small pieces of sensitive terrain (Figure 1B). So the dominant structures around access to land-the 1992 land policy regime and the subsequent land scarcity-exacerbate the flooding risk at local levels.

At the same time, dominant structures influence the available alternatives for adaptive migration. First and foremost, tropical storms are driving displacement, and yet the total number of migrants from affected communities well exceeds the number displaced. For 
Population change in Santa Rosa de Aguán

$(\sim 7,200$ in 1997 to 3,787 in 2001)

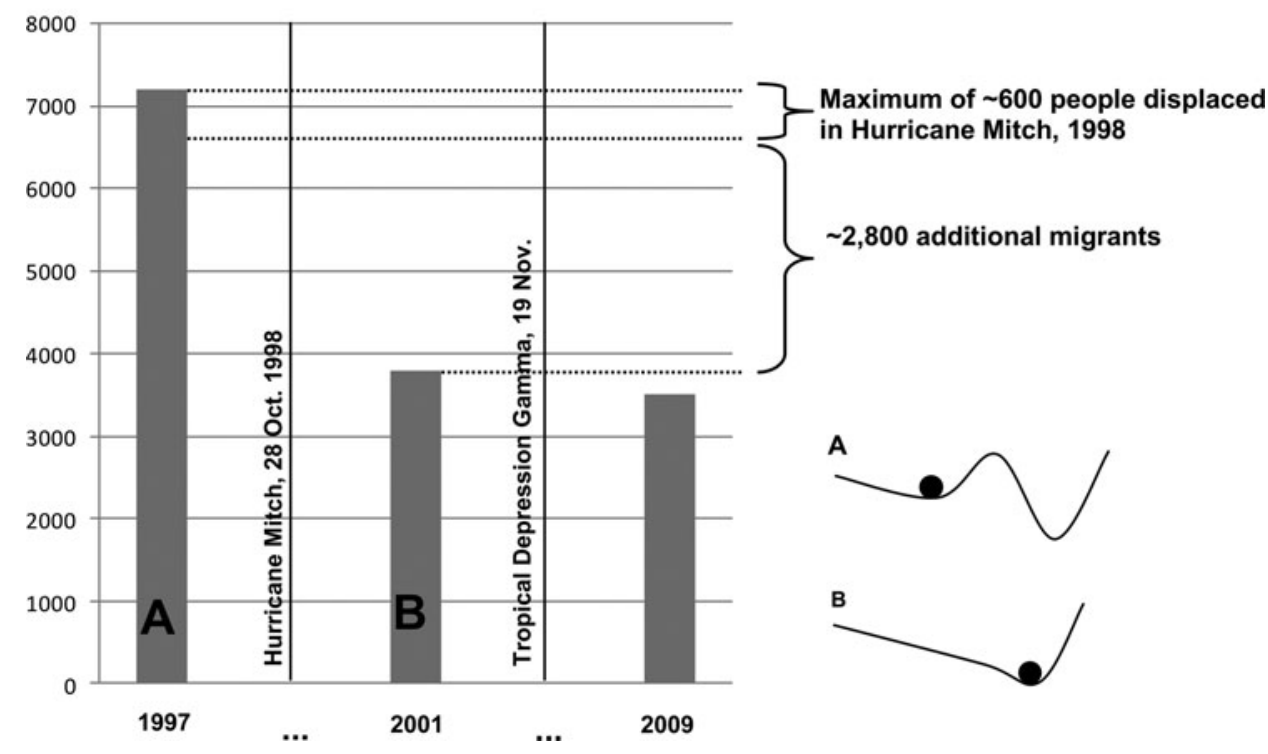

Figure 2. Catastrophic flooding and population change in Santa Rosa de Aguán, Honduras. Although a maximum of $\sim 600$ were displaced in the initial storm, a much larger population migrated (A) and (B). This population profile remains relatively stable through time despite other major storm impacts and massive investment in resettlement projects.

example, according to cadastral records in Santa Rosa de Aguán, a village that was catastrophically flooded in 1998 with Hurricane Mitch, the predisaster population was approximately 7,200. And yet, although a maximum of 600 individuals were displaced, the census taken in 2001 found 3,787 individuals in the municipality. Nearly 3,000 additional people migrated. In 2009, eleven years following the initial disaster, the cadastre reported a population of about 3,500 — half the predisaster population-despite an increase in the overall number of domiciles in the municipality, including 445 new homes in four different resettlement projects (Figure 2).

At closer inspection, the trend in migration is different from historical modes for a number of reasons. First, from the perspective of human timescales, land is permanently disappearing, and there is no substantive regeneration. Displaced households can obtain land within the village in increasingly vulnerable areas or further away from the village and their fields. So in new circumstances, a majority of displaced households sold plots because, like Paulo, "we no longer had access to it anyway. Ours was on the far side of the river, and so after relocating here, we couldn't get to it easily." Obtaining land for resettlements, another adaptation strategy, was fraught with the same problems of land conflict outlined earlier. Four resettlement organizers (in each of the communities in the study) reported being physically threatened for their efforts to obtain land for resettlement projects, and one organizer in Santa Rosa de Aguán, the son of a respondent, was murdered as he petitioned land from a rancher. Because adaptation alternatives within the villages are limited by land scarcity, people adapted to environmental stress by liquidating vulnerable assets in and around the village, investing in strategies outside of the villages: more permanent modes of migration. One respondent described the general effect:

People used to leave here by the dozen and go to New York. At that time, people used to bring money back and it would enrich everybody, and there was work for everybody in the village. I would build three houses, and earn USD $\$ 10,000$ ! But now, that money is gone. You don't see the investment in the village anymore, and now you can't find jobs. This is a problem that has affected the whole community.

This new migration dynamic led a period of economic decline and thus reinforced the persistent need for adaptive migration. "There were no jobs here!" respondents expressed, "So, I had to leave." In this way, land scarcity, migration, and the cascading effects have led to the emergence of a demographic profile that is relatively stable through time: Those with suitable alternatives left, whereas others with diminishing prospects stayed behind (Figure 2B). One respondent elegantly described the process, "In those first months after the storm, I would have stayed, but everybody was planning to leave, and so I had to decide to leave, too." 


\section{Glacier Recession, Dominant Water Provisioning Structures, and Migration in Peru}

Just as land availability is critical for livelihood function, so is water provisioning, and climate change and glacier recession are changing water availability in the Tropical Andes. In Peru's Santa River catchment, glaciers function to regulate water flow interannually, maintaining stability in ecological systems and supplying water to a host of regional users through both wet and dry seasons. Historic and multiscalar observations, however, identify an acceleration of glacier melt across several decades, a nonlinear trend in the downstream hydrological regime, and diminishing water supplies to dependent smallholders during the dry season (Mark et al. 2010). During the twentieth century, glacier cover over the Cordillera Blanca has declined from 800 to $850 \mathrm{~km}^{2}$ in 1930 to slightly less than $600 \mathrm{~km}^{2}$ at the end of the twentieth century (Georges 2004). During the past few decades, water resources in the Cordillera Blanca crossed a threshold of "peak water" (Baraer et al. 2012). New hydrological assessments based on hydrological data analysis and numerical modeling of nine glacierized tributary watersheds of the Santa River indicate an evolution of glacier hydrology through four impact phases of climate change (Figure 3 ). The over-

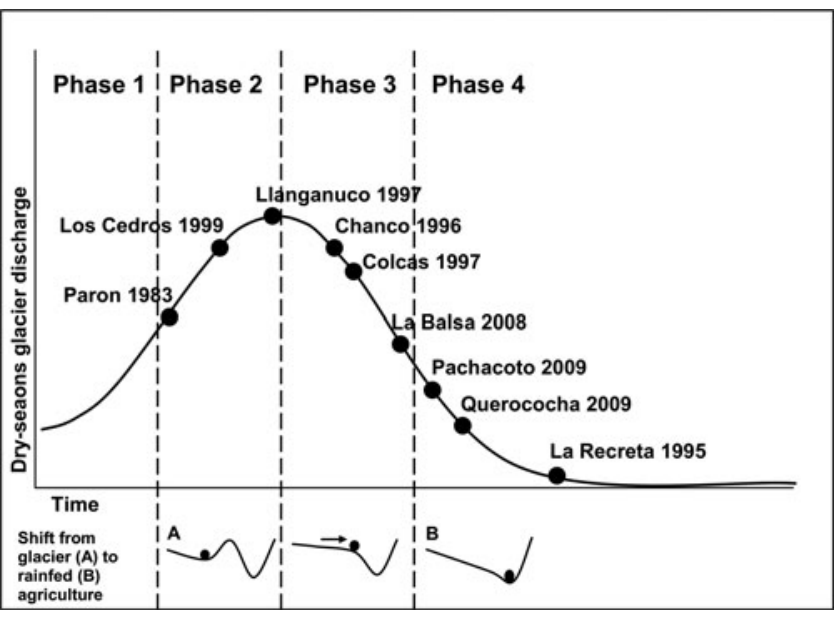

Figure 3. Four climate change impact phases of dry-season glacial discharge. Phase 1: Increasing dry-season and yearly average discharges (as glaciers begin to recede); Phase 2: Annual average discharge reaches a "peak" (due to reduced glacier masses and diminishing dry season discharges); Phase 3: A pronounced decrease in discharges (as glacier recession stabilizes); Phase 4: The end of glaciers' influence on dry-season outflows. Points indicate the allocation of nine subcatchments in the Cordillera Blanca across the four phases. all state of studied watersheds indicates that, on average, glacier-fed rivers are experiencing an increase in discharge variability and a decrease in dry-season discharge (Phase 3), and it is likely that the Santa River's peak discharge occurred around 1980. One of the Phase 3 watersheds, La Balsa, likely crossed the threshold from Phase 2 near 1970. These nine subcatchments form the basis for quasi-experimental comparison of migration behaviors, and hydrological modeling was paired with survey and ethnographic research in settlements along three of these subcatchments, the districts of Yungay (Phase 2), Huaraz (Phase 3), and Catac (Phase 4).

In Peru, water-provisioning systems have been a critical basis of human settlements across the Western Pacific slope for millennia, largely because only 2 percent of the country's total fresh water flows through the arid west. Highland smallholders in the Cordillera Blanca historically utilized glacial meltwater to provide yearround water for the cultivation of staples and market crops. Since the conquest of Peru in the mid-1500s, the structures of domination that govern hydraulic relations in the region have been based on highly unequal access to water resources and distribution systems. Generally, through the colonial and neocolonial periods, access to water resources (and jointly arable land resources) was mediated by hacienda institutional control in the highlands and by large sugarcane plantations along the coast (Galeano 1973; Thorp and Bertram 1978). Nevertheless, during this time, smallholders in the upper catchments independently relied on often decentralized and ad hoc access to irrigation systems and springs. Beginning in the late 1960s, though, new agrarian reform movements and successive revolutionary military dictatorships partially restructured land and water institutions across the highlands, fostering the growth of smallholder agriculture and livelihood systems and the creation of new water use and distribution institutions (Cameron 1994). This evolution in water governance regimes coincided with a national economic strategy beginning in the 1990s that prioritized export-led growth (Bury 2005). Heavy concentrations of infrastructural investments on the coast began a process of rapid emigration from the rural highlands and urbanization of the coast that is sustained through the present, so that today Peru is one of the most urbanized countries in South America (Álvarez-Berríos et al. 2013). This relatively recent pattern of demographic transformation is still unfolding in the Cordillera Blanca as populations move coastward (Bury, Mark, and McKenzie 2013).

During this revolutionary period and through the mid-1970s, water governance remained spatially 
discrete across the steep Andean coastal escarpment that links coastal and highland altitudinal zones. Water resource use along the coast intensified significantly as new large-scale national agricultural initiatives and water distribution systems such as Chinecas and Chavimochic were developed (Kus 1987). The growing water needs of coastal plantation and urban centers shifted the locus of water management upstream. Over the past decade, due to the limits to freshwater availability and increasing intensification of water use, coastal and highland water users and management institutions have become increasingly linked across geographic and political scales.

In the Santa River watershed of the Cordillera Blanca, a number of new tensions related to water resources have recently begun to emerge. In its more than $300-\mathrm{km}$ course, the Santa River articulates the water demands of highland agro-pastoralists, growing urban centers, a U.S.-owned hydropower company, extractive industries, and numerous agro-exporters producing crops like asparagus, tamarind, and paprika for distant markets (Mark et al. 2010; Carey, Huggel et al. 2012; Bury, Mark, and McKenzie 2013). Facing mounting competition and conflicts between economic sectors, Peruvian lawmakers passed new water legislation in 2009 premised on the concept of integrated water management. Conceptually, the law is attractive for its emphasis on balancing different environmental, cultural, and economic values of water, as well as for its ambitious reconfiguration of the institutional landscape of hydrologic resource management in Peru. Yet, the institutional flexibility necessary to implement the law's ambitious vision demands collaboration and compromise across the factious political and economic sectors, including broad public participation (Autoridad Nacional del Agua 2009). This increasing institutional interconnectedness has begun a period of conflict over access to water resources and distribution with several high-profile disputes, including the conflict between campesino organizations and Duke Energy at Lake Paron (Carey, French, and O'Brien 2012). Water laws present opportunities for powerful economic actors to control water resources even further, increasing the rigidity of water provisioning systems across the region.

Climate-driven hydrological trends in the Santa River watershed are already decades old and, in conjunction with other climate-change-related stresses, are driving new patterns of migration behavior. Migration is motivated by livelihood stress, but the form that it takes is shaped by dominant institutional forces. Semistructured interviews conducted with households across all nine watersheds support the "peak water" hypothesis and its implicit risks to livelihoods. For example, respondents from communities in Phase 2 subcatchments reported risks from a superabundance of water as canal water levels were at maximum during 2012 and threatened land and crops through flooding and soil erosion. Conversely, communities in Phase 4 subcatchments reported in 2012 that canals were empty halfway through the dry season, which led to significant crop mortality. In addition, respondents reported switching completely from irrigation to rain-fed agriculture, which has increased the risks to crops from increasing weather and temperature extremes. Households across the upper Santa watersheds have widely reported increasing extremes in daily and seasonal temperature and weather variability. This includes factors such as colder nighttime temperatures, warmer and drier daytime conditions, and precipitation events that have become more extreme and are occurring more frequently during the dry season (see also Bury et al. 2011). Whereas historically smallholders irrigated fields once weekly, because of warmer daytime temperatures, crops must be irrigated at more frequent intervals. At the same time, heavy frosts have been more intense and have occurred more frequently during the growing season. Frosts pose a risk to household livelihoods in all catchments, regardless of water abundance. As Victor, a rural smallholder, described the challenge to livelihoods in Phase 2 catchments, "We still have water, and we can adapt to the pests and poor quality soil with pesticides and fertilizer, but there is no adaptation to the cold nights."

Households facing risks have begun to pursue new resource diversification strategies, including an increasing reliance on migration and remittances. Semistructured interviews conducted in 2012 with migrants across the region indicated that increasing livelihood risks are intensifying historical population dynamics and migration behavior. Relative to respondents in Phase 2 subcatchments, respondents in Phase 4 subcatchments reported increasing expectations that young members of their household will migrate to Peru's cities and remit money to contribute to household budgets back home. Population data illustrate this relationship between livelihood risk and migration: Communities in subcatchments in the more advanced stages of hydrologic change where households are switching to rain-fed agriculture (Phases 3 and 4) have the most fragmented populations (Figure 4). Environmental stress is concomitant with higher concentrations of elderly people and absent working-age populations relative to those areas with more regular water supplies. This trend was consistently 


\section{Yungay, Peru pop. 20,075 (Superimposed in grey) Recuay, Peru pop. 5,015 (in red and blue) Llanganuco Watershed (Phase 2) \\ Pachacoto Watershed (Phase 4)}
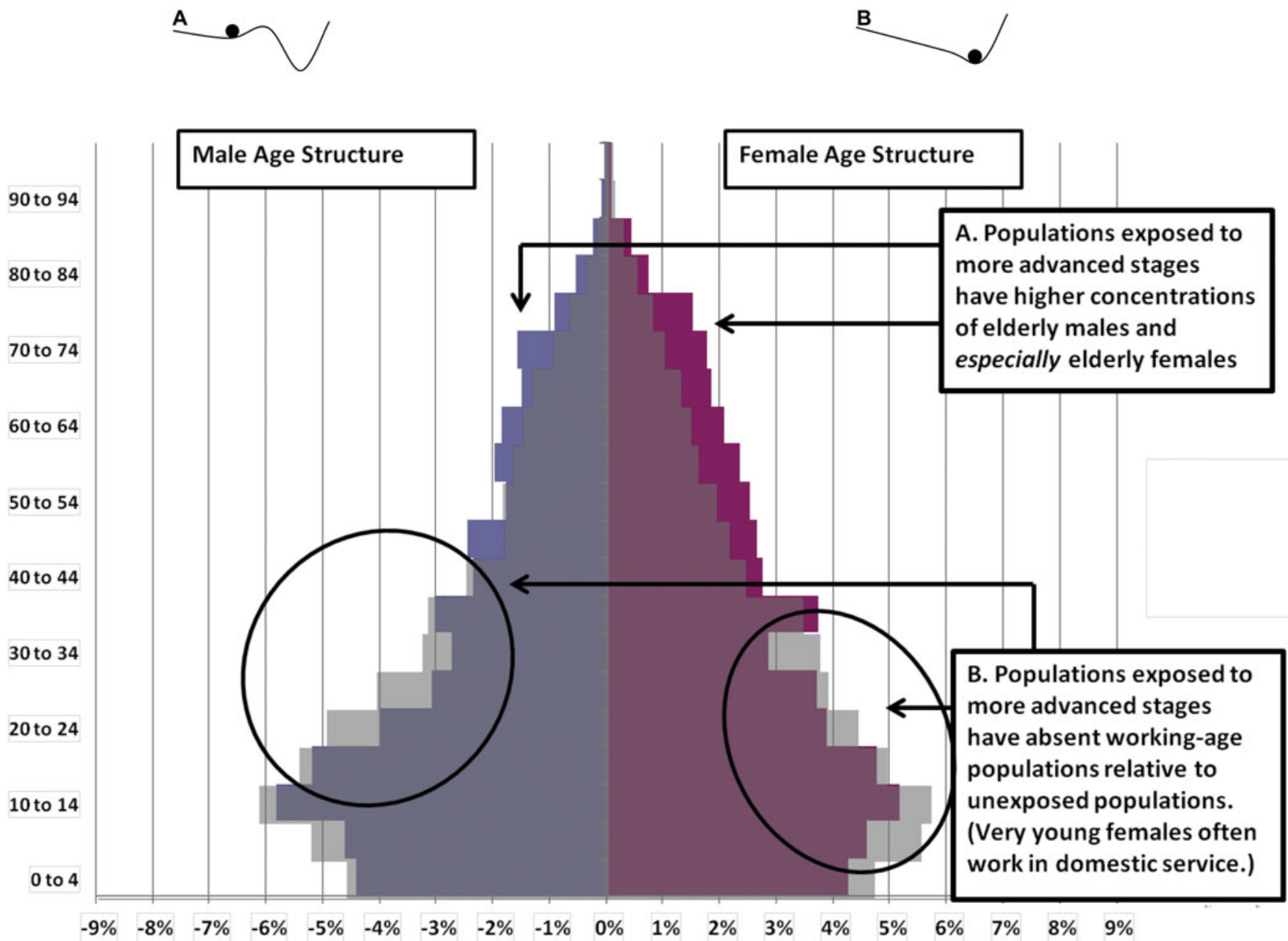

Figure 4. A demographic shift: A comparison of populations in different climate impact phases. Age of population ( $y$ axis) against total population ( $x$ axis). (Color figure available online.)

observed in our study areas, and ground-truthed in field visits.

Households also indicated widespread preoccupation with larger, and more sudden, climate change-related risks such as glacier lake outburst floods (GLOFS) and avalanches, both of which have occurred repeatedly over the past few decades with devastating consequences for the lives and livelihoods of people beneath the glaciers of the region (Carey 2010; Carey, Huggel et al. 2012). In past decades, GLOFs and glacier landslides have killed more than 20,000 residents, and there have been subsequent population relocations, both in the immediate areas destroyed by these disasters and more widespread emigration from the effected regions. After the $1941 \mathrm{GLOF}$, for example, the downtown section of the destroyed city of Huaraz was left empty for decades while people resettled and rebuilt elsewhere in the city. After the zone's catastrophic earthquake and Yungay avalanche in 1970 that killed a combined 55,000 people, thousands of middle- and upper-class urban residents emigrated to Lima. As those residents fled the region's urban areas in the disaster's aftermath, rural farmers inhabiting upland slopes migrated to the partially vacated urban areas in search of aid, food, and shelter so that one third of the Callejón de Huaylas population inhabited urban areas by the early 1970s (Walton 1974).

Like Honduras, the dominant structures for water resource provisioning limit the available adaptation alternatives and accelerate existing modes of migration as the most desirable among a dwindling set of possibilities. Cesar, a smallholder in Catac, reported that in 
the switch to rain-fed agriculture, water provisioning is as much a function of stream flows as it is about new restrictions on use.

Because of the shortages, we're required to share the small amount of water that we have. There are lots of restrictions and rules about water use, more than in the past. We're taking lessons from the communities that already rely on rain-fed agriculture.

New restrictions meet headlong with aspirations of the younger generation, who "don't want to farm because there are easier, more productive alternatives" like mining, manual labor, and construction. What appears as the expression of agency in adaptation, however, is also a reflection of limited alternatives. As Rafael stated, "Young people couldn't stay here even if they wanted to because there is less water and more rules."

\section{Discussion}

The most significant difference between the sites is the nature of climate disturbances, the time frame of exposure, and forcing: Glacier melting is a secular change (nonperiodic, long term) with progressive unfolding (albeit with enhanced likelihood of secondary shocks like GLOFs), whereas tropical storms are near instantaneous from a resource change perspective and difficult to predict with specificity but will be increasingly likely given progressive intensification of the boundary forcings (higher sea surface temperatures, enhanced tropospheric heat, and water cycling). Furthermore, within each context, often subtle but significant differences existed in the way dominant structures were expressed between communities. For example, some Garífuna villages were surrounded by African palm, whereas others were surrounded by cattle ranches. Likewise, some of the study areas in Peru were home to mining operations, which introduced specific dynamics in water competition. Despite these differences, in both cases, structures of domination generally shaped the new forms that migration took in the presence of climate stress (Figure 2 and Figure 4). In Honduras, migrants from wealthier social strata are moving on a more permanent basis, and in Peru, the once historical pattern of labor migration is becoming a practical necessity.

The analysis so far has focused on adaptation within community scales, but structures of dominance have significant implications for broader scales. First, it is tempting to praise emigration and increased reliance on remittances as a novel form of adaptation, but this dynamic reinforces inequitable structures. In Honduras, for ex- ample, displaced Garífuna households reported selling lands to mid-and large-scale mestizo cattle ranchers on the peripheries of the villages to cope with economic losses, repay debts, and manage future risks. Environmental stress and migration become a mechanism by which indigenous controlled lands are inserted into the private market and ceded to nonindigenous tenants. This has implications for the social and political cohesiveness of the entire indigenous group. In Peru, migration was reported to serve as a pressure valve, loosening households' dependence on water, such that competition over remaining resources favors vested stakeholders in the Santa River. In the context of decreasing water availability and ever more inflexible and interconnected water provisioning, smallholder households must compete with powerful water consumers to secure alternatives for in situ adaptation. Several high-profile cases of water conflict between communities and waterintensive industries, such as hydropower and mining operations, are evidence of rigidity in the system (Carey, French, and O'Brien 2012; Lynch 2012). When young people migrate, it reduces demand and resolves the conflict.

\section{Conclusion}

Environmental stress and adaptation alternatives, like migration, are historically derived and politically embedded. This conceptualization goes beyond viewing migration as adaptation or lack thereof but rather as an aspect of a shift produced by fundamental structures of power and domination that circumscribe options for local adaptations and instead promote alternatives, like migration, that displace adaptation to other geographical spaces. Reinserting an analysis of power relations at the heart of adaptive systems approaches coincides with the agenda of political ecology by encouraging a formulation of social-ecological structures that delimit access to resources (Heynen, Kaika, and Swyngedouw 2006; Pelling 2010). Moreover, by shedding light on the politics that order inequalities in the opportunity to adapt, scholarship on environmental change and human and political ecology can provide insight into the interaction of human agency and social (ecological) structure (Tompkins and Adger 2004; Eriksen et al. 2011).

In particular, more research must be devoted to the capacities of vulnerable people to adapt in new social-ecological states-the rigidity traps-that emerge as environmental stress and migration feedback against each other and how those traps can be mitigated. This article comes at a timely policy 
moment in the United Nations Framework Convention on Climate Change negotiations, with international agreement to clarify modalities of human mobility visà-vis climate change in future conferences of parties. It is imperative to move discourses about climate change adaptation - and particularly climate-induced displacement and migration - away from environmental determinism and toward social-ecological possibilism. Political economies constrain adaptive alternatives and force the undesirable scenarios in which migration occurs. In this respect, geography, for its multidisciplinary emphasis on both environmental change and resource politics, is particularly well situated for advancing this area of policy and research at a critical juncture in human history.

\section{References}

Adger, W. N., S. Dessai, M. Goulden, M. Hulme, I. Lorenzoni, D. Nelson, L. Naess, et al. 2009. Are there limits to social adaptation to climate change. Climatic Change 93 (3-4): 335-54.

Allison, H. E., and R. J. Hobbs. 2004. Resilience, adaptive capacity, and the lock-in trap of the Western Australian agricultural region. Ecology and Society 9 (1): 3.

Álvarez-Berríos, N. L., I. K. Parés-Ramos, and T. M. Aide. 2013. Contrasting patterns of urban expansion in Colombia, Ecuador, Peru, and Bolivia between 1992 and 2009. Ambio 42 (1): 29-40.

Anderies, J. M., B. H. Walker, and A. P. Kinzig. 2006. Fifteen weddings and a funeral: Case studies and resilience-based management. Ecology and Society 11 (1): 21.

Anderson, M. 2007. When Afro becomes (like) indigenous: Garífuna and Afro-indigenous politics in Honduras. The Journal of Latin American and Caribbean Anthropology 12 (2): 384-413.

-2009. Black and indigenous: Garífuna activism and consumer culture in Honduras. St. Paul: University of Minnesota Press.

Autoridad Nacional del Agua. 2009. Ley de Recursos Hidricos \#29338; M.T. Oré, L. Castillo, S. Van Orsel and J. Vos. El agua, ante nuevos desafios: Actores e iniciativias en Ecuador, Perú, y Bolivia, Lima.

Baraer, M., G. Bryan, J. McKenzie, T. Condom, and S. Rathay. 2012. Glacier recession and water resources in Peru's Cordillera Blanca. Journal of Glaciology 58 (207): 134-50.

Bardsley, D. K., and G. J. Hugo. 2010. Migration and climate change: Examining thresholds of change to guide effective adaptation decision-making. Population $\mathcal{E}$ Environment 32 (2-3): 238-62.

Bender, M. A., T. R. Knutson, R. E. Tuleya, J. J. Sirutis, G. A. Vecchi, S. T. Garner, and I. M. Held. 2010. Modeled impact of anthropogenic warming on the frequency of intense Atlantic hurricanes. Science 327 (5964): 454-58.

Bird, A. 2011. Drugs and business: Central America faces another round of violence. NACLA Report on the Americas 45 (1): 35-36.
Black, R., W. N. Adger, N. W. Arnell, S. Dercon, A. Geddes, and D. Thomas. 2011. The effect of environmental change on human migration. Global Environmental Change 21:S3-S11.

Black, R., S. R. G. Bennett, S. M. Thomas, and J. R. Beddington. 2011. Climate change: Migration as adaptation. Nature 478 (7370): 447-49.

Budds, J., and L. Hinojosa. 2012. Restructuring and rescaling water governance in mining contexts: The coproduction of waterscapes in Peru. Water Alternatives 5 (1): 119-37.

Bury, J. 2005. Mining mountains: Neoliberalism, land tenure, livelihoods, and the new Peruvian mining industry in Cajamarca. Environment and Planning A 37 (2): 221-39.

Bury, J., B. G. Mark, and J. M. McKenzie. 2013. New geographies of water and climate change in Peru: Coupled natural and social transformations in the Santa River watershed. Annals of the Association of American Geographers 103 (2): 363-74.

Bury, J. T., B. G. Mark, J. M. McKenzie, A. French, M. Baraer, K. I. Huh, M. A. Zapata Luyo, and R. J. Gómez López. 2011. Glacier recession and human vulnerability in the Yanamarey watershed of the Cordillera Blanca, Peru. Climatic Change 105 (1): 179-206.

Cameron, M. A. 1994. Democracy and authoritarianism in Peru: Political coalitions and social change. London: Palgrave Macmillan.

Carey, M. P. 2010. In the shadow of melting glaciers: Climate change and Andean Society. New York: Oxford University Press.

Carey, M., A. French, and E. O'Brien. 2012. Unintended effects of technology on climate change adaptation: An historical analysis of water conflicts below Andean glaciers. Journal of Historical Geography 38 (2): 181-91.

Carey, M., C. Huggel, J. Bury, C. Portocarrero, and W. Haeberli. 2012. An integrated socio-environmental framework for glacier hazard management and climate change adaptation: lessons from Lake 513, Cordillera Blanca, Peru. Climatic Change 112 (3-4): 733-67.

Carpenter, S. R., and W. A. Brock. 2008. Adaptive capacity and traps. Ecology and Society 13 (2): 40.

Cochran, D., C. Reese, and K. Liu. 2009. Tropical Storm Gamma and the Mosquitia of eastern Honduras: A littleknown story from the 2005 hurricane season. Area 41 (4): 425-34.

Eakin, H., E. L. Tompkins, D. R. Nelson, and J. M. Anderies. 2009. Hidden costs and disparate uncertainties: Tradeoffs involved in approaches to climate policy. In Adapting to climate change, ed. W. N. Adger, I. Lorenzoni, and K. L. O'Brien, 212-26. London: Cambridge University Press.

England, S. 2006. Afro-Central Americans in New York City: Garifuna tales of transnational movements in radicalized space. Gainesville: University Press of Florida.

Eriksen, S., P. Aldunce, C. S. Bahinipati, R. D. A. Martins, J. I. Molefe, C. Nhemachena, K. O'Brien, et al. 2011. When not every response to climate change is a good one: Identifying principles for sustainable adaptation. Climate and Development 3 (1): 7-20.

Feng, S., A. B. Krueger, and M. Oppenheimer. 2010. Linkages among climate change, crop yields and Mexico-US cross-border migration. Proceedings of the National Academy of Sciences 107 (32): 14257. 
Folke, C. 2006. Resilience: The emergence of a perspective for social-ecological systems analyses. Global Environmental Change 16 (3): 253-67.

Galeano, E. H. 1973. Open veins of Latin America. New York: Monthly Review Press.

García, S. C. 2001. Historia del pueblo negro caribe y su llegada a las Hibueras el 12 de abril de 1797 [History of the Black Caribs and their arrival to Hibueras, Honduras the 12th of April 1797]. Universidad Nacional Autónoma de Honduras, Editorial Universitaria.

—. 2004. Adhesión étnica [Ethnic adhesion]. Universidad Nacional Autónoma de Honduras, Editorial Universitaria.

Georges, C. 2004. 20th-century glacier fluctuations in the Tropical Cordillera Blanca, Peru. Arctic, Antarctic, and Alpine Research 36 (1): 100-107.

Giddens, A. 1984. The constitution of society: Introduction of the theory of structuration. Cambridge, UK: Polity Press.

Gonzalez, N. L. 1988. The sojourners of the Caribbean: Ethnogenesis and ethnohistory of the Garifuna. Urbana: University of Illinois Press.

Gray, C. L., and V. Mueller. 2012. Natural disasters and population mobility in Bangladesh. Proceedings of the National Academy of Sciences 109 (16): 6000-05.

Heynen, N., M. Kaika, and E. Swyngedouw. 2006. Urban political ecology. In The nature of cities: Urban political ecology and the politics of urban metabolism, 1-20. London and New York: Taylor \& Francis.

Hugo, G. 2008. Migration, development and environment. Geneva, Switzerland: International Organization for Migration.

- 2011. Future demographic change and its interactions with migration and climate change. Global Environmental Change 21:S21-S33.

Hummel, D., S. Adamo, A.deSherbinin, L. Murphy, R. Aggarwal, L. Zulu, J. Liu, et al. 2012. Inter-and transdisciplinary approaches to population-environment research for sustainability aims: A review and appraisal. Population $\mathcal{E}$ Environment 34 (4): 481-509.

Intergovernmental Panel on Climate Change. 2012. Managing the risks of extreme events and disasters to advance climate change adaptation. A special report of working groups I and II of the Intergovernmental Panel on Climate Change, ed. C. B. Field, V. Barros, T. F. Stocker, D. Qin, D. J. Dokken, K. L. Ebi, M. D. Mastrandrea, K. J. Mach, G.-K. Plattner, S. K. Allen, M. Tignor, and P. M. Midgley. Cambridge, UK: Cambridge University Press.

Jansen, K., and E. Roquas. 1998. Modernizing insecurity: The land titling project in Honduras. Development and Change 29 (1): 81-106.

Kus, J. S. 1987. Chavimochic: A Peruvian irrigation project. Syracuse, NY: Syracuse University Press.

Leach, M., R. Mearns, and I. Scoones. 1999. Environmental entitlements: Dynamics and institutions in communitybased natural resource management. World Development $27(2): 225-47$.

Lilleør, H. B., and K. Van den Broeck. 2011. Economic drivers of migration and climate change in LDCs. Global Environmental Change 21:S70-S81.

Liverman, D. 2009. Conventions of climate change: Constructions of danger and the dispossession of the atmosphere. Journal of Historical Geography 35 (2): 279 96.
Loarie, S. R., P. B. Duffy, H. Hamilton, G. P. Asner, C. B. Field, and D. D. Ackerly. 2009. The velocity of climate change. Nature 462 (7276): 1052-55.

Lynch, B. D. 2012. Vulnerabilities, competition and rights in a context of climate change toward equitable water governance in Peru's Rio Santa Valley. Global Environmental Change 22 (2): 364-73.

Mark, B. G., J. Bury, J. M. McKenzie, A. French, and M. Baraer. 2010. Climate change and tropical Andean glacier recession: Evaluating hydrologic changes and livelihood vulnerability in the Cordillera Blanca, Peru. Annals of the Association of American Geographers 100 (4): 794-805.

McLeman, R. A., and L. M. Hunter. 2010. Migration in the context of vulnerability and adaptation to climate change: Insights from analogues. Wiley Interdisciplinary Reviews: Climate Change 1 (3): 450-61.

McLeman, R., and B. Smit. 2006. Migration as an adaptation to climate change. Climatic Change 76 (1): 3153.

Mollett, S. 2006. Race and natural resource conflicts in Honduras: The Miskito and Garifuna struggle for Lasa Pulan. Latin American Research Review 41 (1): 76-101.

- 2011. Racial narratives: Miskito and colono land struggles in the Honduran Mosquitia. Cultural Geographies 18 (1): 43.

Peet, R., P. Robbins, and M. Watts. 2011. Global political ecology. London and New York: Routledge.

Pelling, M. 2010. Adaptation to climate change: From resilience to transformation. London and New York: Taylor \& Francis.

Pelling, M., and D. Manuel-Navarrete. 2011. From resilience to transformation: The adaptive cycle in two Mexican urban centers. Ecology and Society 16 (2): 11.

Raleigh, C., and L. Jordan. 2010. Climate change and migration: Emerging patterns in the developing world. In Social dimensions of climate change: Equity and vulnerability in a warming world, ed. R. Mearns and A. Norton, 103-31. Washington, DC: The World Bank.

Renaud, F. 2007. Control, adapt or flee: How to face environmental migration? Bonn, Germany: United Nations University-Environment and Human Security.

Rocheleau, D. E. 2008. Political ecology in the key of policy: From chains of explanation to webs of relation. Geoforum $39(2): 716-27$.

Scheffer, M., J. Bascompte, W. A. Brock, V. Brovkin, S. R. Carpenter, V. Dakos, H. Held, et al. 2009. Early-warning signals for critical transitions. Nature 461 (7260): 53-59.

Scheffer, M., F. Westley, W. A. Brock, and M. Holmgren. 2002. Dynamic interaction of societies and ecosystems-Linking theories from ecology, economy and sociology. In Panarchy: Understanding transformations in human and natural systems, ed. L. H. Gunderson and C. S. Holling, 195-240. London: Island.

Soluri, J. 2005. Banana cultures: Agriculture, consumption, and environmental change in Honduras and the United States. Austin: University of Texas Press.

Tacoli, C. 2009. Crisis or adaptation? Migration and climate change in a context of high mobility. Environment and Urbanization 21 (2): 513.

Thorp, R., and G. Bertram. 1978. Peru, 1890-1977: Growth and policy in an open economy. New York: Columbia University Press. 
Tompkins, E. L., and W. N. Adger. 2004. Does adaptive management of natural resources enhance resilience to climate change? Ecology and Society 9 (2): 10.

Walker, B. H., L. H. Gunderson, A. Kinzig, C. Folke, S. R. Carpenter, and L. Schultz. 2006. A handful of heuristics and some propositions for understanding resilience in social-ecological systems. Ecology and Society 11 (1): 13.

Walton, N. K. 1974. Human spatial organization in an Andean valley: The Callejón de Huaylas, Peru. PhD disserataion, University of Georgia, Athens, GA.
World Bank. 2012. Turn down the heat: Why a $4^{\circ} \mathrm{C}$ warmer world must be avoided. Washington, DC: World Bank.

Wrathall, D. J. 2012. Migration amidst social-ecological regime shift: The search for stability in Garífuna villages of northern Honduras. Human Ecology 40 (4): 583-96.

Young, O. R., F. Berkhout, G. C. Gallopin, M. A. Janssen, E. Ostrom, and S. van der Leeuw. 2006. The globalization of socio-ecological systems: An agenda for scientific research. Global Environmental Change 16 (3): 304 16.

Correspondence: Institute for Environment and Human Security, United Nations University, UN Campus, Hermann-Ehlers-Str 10. 53113 Bonn, Germany, e-mail: wrathall@ehs.unu.edu (Wrathall); Department of Environmental Studies, University of California Santa Cruz, Room 428, Interdisciplinary Sciences Building, 1156 High Street, Santa Cruz, CA 95064, e-mail: jbury@ucsc.edu (Bury); crampini@ucsc.edu (Rampini); Clark Honors College, University of Oregon, 101C Chapman, 1585 E. 13th Avenue, Eugene, OR 97403, e-mail: carey@uoregon.edu (Carey); Department of Geography, The Ohio State University, 1136 Derby Hall, 154 Oval Mall, Columbus, OH 43210-1341, e-mail: Mark.9@osu.edu (Mark); Department of Earth and Planetary Sciences, McGill University, 3450 University Street, Montreal, PQ, H3A OE8, Canada, e-mail: Jeffrey.mckenzie@mcgill.ca (McKenzie); Department of Geography and the Environment, University of Texas, Austin, CLA 3.422, A3100, 305 E. 23rd Street, Austin, TX 78712, e-mail:kryoung@austin.utexas.edu (Young); École de technologie supérieure, Université du Québec, 100 Rue Notre Dame Quest, Montreal, QC, H3C 1K3, Canada, e-mail: michel.baraer@etsmtl.ca (Baraer); Department of Environmental Studies, University of California Berkeley, 310 Barrows Hall, Berkeley, CA 94720-3050, e-mail: akfrench@ucsc.edu (French). 